\title{
Methylmercury formation in the anoxic waters of the Petit-Saut reservoir (French Guiana) and its spreading in the adjacent Sinnamary River
}

\author{
M. Coquery, D. Cossa ${ }^{1}$, T. Peretyazhko², S. Azemard, L. Charlet ${ }^{2}$ \\ International Atomic Energy Agency, Marine Environmental Laboratory, B.P. 800, F-98000 Monaco \\ ${ }^{1}$ Ifremer, Centre de Nantes, BP 21105, F-44311 Nantes Cedex 03, France \\ 2 Laboratoire de Géophysique Interne et Tectonophysique, University of Grenoble-1, BP53, F-38041 \\ Grenoble, France
}

\begin{abstract}
The present work was carried out on the hydroelectric reservoir Petit-Saut on the Sinnamary river in French Guiana. Measurements were performed during the wet and dry seasons along a longitudinal gradient, from upstream of the reservoir in two inflow rivers, to the Sinnamary estuary downstream of the dam. Gold extraction has led to a marked increase in suspended matter and total mercury $(\mathrm{HgT})$ in one of the rivers. Dissolved monomethylmercury (MMHg) measured in surface waters were similar for both rivers: 0.03-0.05 ng 1-1 $(1.0-1.7 \%$ of the dissolved $\mathrm{HgT}$ ). These results indicate similar methylation efficiency and/or transfer of $\mathrm{MMHg}$ into the dissolved fraction of the water column, independently of the amounts of inorganic mercury transported. Dissolved $\mathrm{MMHg}$ concentrations in surface waters of the reservoir were similar to those in the rivers, but were more than 10 times higher in deep anoxic waters, up to $0.6 \mathrm{ng} \mathrm{l}^{-1}(20 \%$ of dissolved $\mathrm{HgT})$. The MMHg concentration profiles in the water column suggest that methylation occurs mainly in anoxic waters and sediments in relation with the activity of sulfate reducing bacteria. Dissolved $\mathrm{MMHg}$ concentrations measured in the Sinnamary at the base of the dam were still high $\left(0.5-0.6 \mathrm{ng} \mathrm{l}^{-1} ; 20\right.$ to $35 \%$ of the dissolved $\left.\mathrm{HgT}\right)$.
\end{abstract}

\section{INTRODUCTION}

This study is a part of the ongoing multidisciplinary programme, "Mercury in French Guiana". The objective of the current work was to determine the sources and speciation of mercury in water basins affected by input of mercury originating from gold mining [1]. Recent studies of the origin and distribution of mercury in the Amazon basin indicate that the main sources of contamination are the release of particulate $\mathrm{Hg}$ as a result of widespread erosion of soils naturally rich in mercury and local inputs of elemental $\mathrm{Hg}\left(\mathrm{Hg}^{0}\right)$ from gold mining activities. The present work was carried out on the hydroelectric reservoir Petit-Saut on the Sinnamary river. This reservoir was filled in 1994, without destruction of the primary equatorial forest in the area covered by the waters, which led to a very slowly evolving anoxia in the water column. The oxycline is now at $-5 \mathrm{~m}$, for a maximal depth of $35 \mathrm{~m}$. As sulfate reducing bacteria are thought to be the principal methylating agents in aquatic systems, the bottom waters of the reservoir were thought to represent an excellent site for mercury methylation.

\section{FIELD SITE AND METHODS}

\subsection{Study site: Petit Saut Reservoir}

The Petit Saut reservoir is located $50 \mathrm{~km}$ off the city of Kourou on the Sinnamary river. The reservoir covers $80 \mathrm{~km}$ of the river course. Impounding started in January 1994 and was completed in July 1995. Maximal depth of the Petit Saut reservoir is $35 \mathrm{~m}$ and the water level varies between 35 and $31.5 \mathrm{~m}$ depending on exploitation of the hydroelectric station. During impounding, approximately $350 \mathrm{~km}^{2}$ of uncleared tropical forest were flooded. Within the dammed water-body the decomposition of submerged vegetation still takes place, with slow degradation kinetics. Possible localized sources of mercury contamination in Petit Saut reservoir include the upstream Saint-Elie gold-mining area, flowing into the reservoir through the Leblond river, and the impounded "Adieu Vat" former mining sites, located near the Roche Genipa sampling site (Fig. 1).

Sampling and measurements were performed in June 1999 (wet season) and December 1999 (end of dry season) along a longitudinal gradient, from upstream of the Petit-Saut reservoir (Coursibo and 
Leblond rivers) to the Sinnamary river and the estuary downstream of the dam. The main vertical profile measurements were carried out at Roche Genipa station (N 4'56'474', W53 $\left.02^{\prime} 468^{\prime \prime}\right)$, located in the middle of the reservoir (Fig. 1).

\subsection{Sampling and analytical methods}

Sub-surface water samples were collected directly by hand in 2-1 Teflon bottles. Water samples for the vertical profiles were collected using an ultra-clean Teflon pumping system or with a teflon-coated Niskin bottle. All Teflon and plastic ware was washed and stored according to the ultraclean procedure [2]. Filtered water samples $(<0.7 \mu \mathrm{m})$ for dissolved total mercury $(\mathrm{HgT})$ were transferred into Teflon bottles (FEP) and acidified with concentrated $\mathrm{HCl}$. Filtered water for monomethylmercury $(\mathrm{MMHg})$ and filters were stored at $-18^{\circ} \mathrm{C}$ before analysis. Analyses of $\mathrm{HgT}$ were performed by reduction with $\mathrm{SnCl}_{2}$, double gold amalgamation and detection by atomic fluorescence spectrometry (AFS). Dissolved HgT was determined after $\mathrm{BrCl}$ oxidation according to the EPA method [3]. Concentrations of particulate $\mathrm{HgT}$ were measured after acid mineralization in Teflon (PFA) reactors. Concentrations of dissolved $\mathrm{MMHg}$ were determined after double extraction using dichloromethane, followed by aqueous phase ethylation, isothermal gas chromatography, and detection by AFS [4]. Method accuracy and precision were checked by analysis of duplicate matrix spikes according to the EPA method [3] and the use of available reference materials (sediments: MESS-2 from the National Research Council of Canada and IAEA-356).
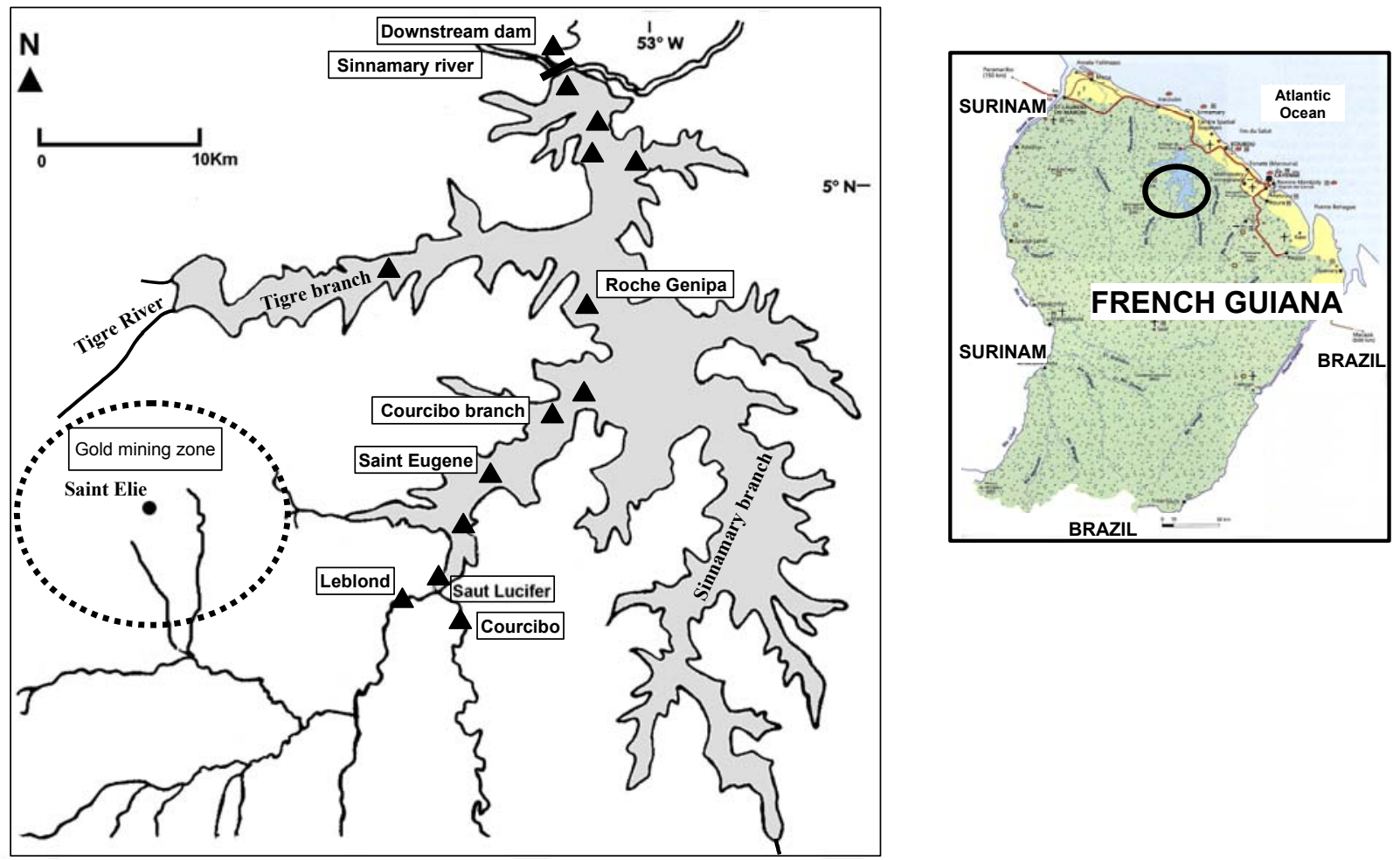

Figure 1. Localization of the study area and sampling sites along the Petit-Saut hydroelectric reservoir in French Guiana.

\section{RESULTS AND DISCUSSION}

Concentrations of dissolved and particulate $\mathrm{Hg}$ measured along the Sinnamary basin are summarized in Table 1 and show comparable values to published data for the Tapajos river and the Amazon river in Brazil [5].

Gold extraction has led to a marked increase in suspended matter (SM) in the Leblond river as compared to the Courcibo river, with mean values 7 and 4-fold higher during dry and wet seasons respectively (Table 1). Total mercury ( $\mathrm{HgT}$ ) concentrations in unfiltered water samples were 16 and 5 times higher in the Leblond river (dry and wet season respectively), with more than $80 \%$ in the particulate fraction. Our results also show marked differences of $\mathrm{HgT}$ concentrations in suspended particles 
expressed in $n g \mathrm{~g}^{-1}$ (x6.5 and $\mathrm{x} 2$ during dry and wet seasons, respectively). These differences could be due to direct mercury input from gold-mining activities and selective soil erosion at mining sites, involving discharge into the river of mercury-enriched particles different from those originating from natural watershed erosion.

In comparison, dissolved $\mathrm{MMHg}$ concentrations measured in surface waters were very close for both rivers with an average of $0.05 \mathrm{ng}^{-1}$ for Leblond and $0.03 \mathrm{ng}^{-1}$ for Courcibo, corresponding to 1 and $1.7 \%$ of dissolved $\mathrm{HgT}$ concentration, respectively. These results indicate similar methylation efficiency and/or transfer of MMHg into the dissolved fraction of the water column, independently of the amounts of inorganic mercury transported by the rivers.

The concentrations of dissolved HgT in surface waters of the reservoir were found to be of the same order of magnitude as the global average for unpolluted waters and were less than 4 ng $1^{-1}$ (Table 1). In both seasons, concentrations of SM, dissolved and particulate HgT decreased along a longitudinal gradient from upstream stations (Saut Lucifer, Coursibo branch, see Fig.1) towards the dam and revealed an enrichment of $\mathrm{HgT}$ due to gold mining in the upstream Saint-Elie area that affects the Leblond river. Dissolved HgT in surface waters averaged $3.6 \mathrm{ng} \mathrm{l}^{-1}$ upstream and was less than $0.7 \mathrm{ng}^{-1}$ near the dam. According to the particulate load of the waters, the particulate mercury, which represented about $80 \%$ of the total mercury upstream, decreased very rapidly and was lower than $45 \%$ near the dam. Total $\mathrm{Hg}$ in suspended particulates also diminished in surface waters from upstream stations towards the dam (460$590 \mathrm{ng} \mathrm{g}^{-1}$ at Saut Lucifer and only 50-133 $\mathrm{ng} \mathrm{g}^{-1}$ near the dam).

In contrast, dissolved $\mathrm{MMHg}$ concentrations in surface waters were similar all along the longitudinal gradient upstream and within the reservoir ( 0.01 to $0.05 \mathrm{ng}^{-1}$, average: $\left.0.02 \pm 0.01 \mathrm{ng} \mathrm{1^{-1 }}\right)$ representing on average $1.8 \%$ of the $\mathrm{HgT}$ and comparable to what was found in the two upstream rivers (Table 1). This relatively low proportion of MMHg is typical for unpolluted surface freshwaters.

Table 1. Suspended particulate matter (SM) and mercury concentrations in the water column

\begin{tabular}{|c|c|c|c|c|c|c|}
\hline & $\begin{array}{c}\mathrm{SM} \\
\left(\mathrm{mg} \mathrm{l}^{-1}\right) \\
\end{array}$ & $\begin{array}{c}\mathrm{HgT} \\
\left(\mathrm{ng} \mathrm{l}^{-1}\right)\end{array}$ & $\begin{array}{c}\text { HgT } \\
\text { dissolved } \\
\left(\mathrm{ng} \mathrm{l}^{-1}\right) \\
\end{array}$ & $\begin{array}{c}\text { HgT } \\
\text { particulate } \\
\left(\mathrm{ng} \mathrm{l}^{-1}\right)\end{array}$ & $\begin{array}{c}\mathrm{HgT} \\
\text { particulate } \\
\left(\mathrm{ng} \mathrm{g}^{-1}\right)\end{array}$ & $\begin{array}{l}\mathrm{MMHg} \\
\text { dissolved } \\
\left(\mathrm{ng} \mathrm{l}^{-1}\right) \\
\end{array}$ \\
\hline $\begin{array}{l}\text { Leblond } \\
\text { river }\end{array}$ & $\begin{array}{l}\text { ds: } 18.7 \pm 0.9 \\
\text { ws: } 36.7 \pm 1.8\end{array}$ & $\begin{array}{l}\text { ds: } 34.9 \pm 5.4 \\
\text { ws: } 25.4 \pm 2.0\end{array}$ & $\begin{array}{l}\text { ds: } 8.2 \pm 1.2 \\
\text { ws: } 2.9 \pm 0.4\end{array}$ & $\begin{array}{l}\text { ds: } 26.7 \pm 5.3 \\
\text { ws: } 22.5 \pm 2.0\end{array}$ & $\begin{array}{l}\text { ds: } 1431 \pm 286 \\
\text { ws: } 613 \pm 55\end{array}$ & $\begin{array}{l}\text { ds: } 0.061 \pm 0.010 \\
\text { ws: } 0.041 \pm 0.008\end{array}$ \\
\hline $\begin{array}{l}\text { Courcibo } \\
\text { river }\end{array}$ & $\begin{array}{l}\text { ds: } 2.6 \pm 0.1 \\
\text { ws: } 9.8 \pm 0.5\end{array}$ & $\begin{array}{l}\text { ds: } 2.1 \pm 0.2 \\
\text { ws: } 5.4 \pm 0.5\end{array}$ & $\begin{array}{l}\text { ds: } 1.5 \pm 0.2 \\
\text { ws: } 2.4 \pm 0.4\end{array}$ & $\begin{array}{l}\text { ds: } 0.6 \pm 0.1 \\
\text { ws: } 3.0 \pm 0.3\end{array}$ & $\begin{array}{l}\text { ds: } 219 \pm 44 \\
\text { ws: } 308 \pm 28\end{array}$ & $\begin{array}{l}\text { ds: } 0.032 \pm 0.008 \\
\text { ws: } 0.026 \pm 0.006\end{array}$ \\
\hline $\begin{array}{l}\text { Petit Saut } \\
\text { reservoir } \\
\text { surface waters }\end{array}$ & $\begin{array}{l}\text { ds: }(4.9-8.6) \\
\text { ws: }(5.2-22)\end{array}$ & $\begin{array}{l}\text { ds: }(0.7-6.8) \\
\text { ws: }(1.1-14.0)\end{array}$ & $\begin{array}{l}\text { ds: }(0.6-3.9) \\
\text { ws: }(0.7-3.3)\end{array}$ & $\begin{array}{l}\text { ds: }(0.3-2.9) \\
\text { ws: }(0.5-11.6)\end{array}$ & $\begin{array}{l}\text { ds: }(34-593) \\
\text { ws: }(59-528)\end{array}$ & $\begin{array}{l}\text { ds: } 0.023 \pm 0.011 \\
\text { ws: } 0.025 \pm 0.014\end{array}$ \\
\hline $\begin{array}{l}\text { Roche Genipa } \\
\text { bottom waters } \\
\text { (below } 10 \mathrm{~m} \text { ) }\end{array}$ & $\begin{array}{l}\text { ds: } 0.6 \pm 0.2 \\
\text { ws: } 4.7 \pm 2.3\end{array}$ & $\begin{array}{l}\text { ds: } 3.9 \pm 0.5 \\
\text { ws: } 4.6 \pm 0.7\end{array}$ & $\begin{array}{l}\mathrm{ds}: 3.6 \pm 0.5 \\
\text { ws: } 2.3 \pm 0.3\end{array}$ & $\begin{array}{l}\text { ds: } 0.3 \pm 0.1 \\
\text { ws: } 2.3 \pm 0.6\end{array}$ & $\begin{array}{l}\text { ds: } 583 \pm 175 \\
\text { ws: } 548 \pm 141\end{array}$ & $\begin{array}{l}\text { ds: } 0.56 \pm 0.15 \\
\text { ws: } 0.38 \pm 0.08\end{array}$ \\
\hline $\begin{array}{l}\text { Sinnamary - } \\
\text { downstream } \\
\text { dam station }\end{array}$ & $\begin{array}{l}\text { ds: } 4.7 \pm 0.3 \\
\text { ws: } 5.4 \pm 0.3\end{array}$ & $\begin{array}{l}\text { ds: } 2.4 \pm 0.7 \\
\text { ws: } 3.4 \pm 0.4\end{array}$ & $\begin{array}{l}\text { ds: } 1.8 \pm 0.7 \\
\text { ws: } 2.4 \pm 0.4\end{array}$ & $\begin{array}{l}\text { ds: } 0.6 \pm 0.1 \\
\text { ws: } 1.0 \pm 0.1\end{array}$ & $\begin{array}{l}\text { ds: } 125 \pm 6 \\
\text { ws: } 176 \pm 16\end{array}$ & $\begin{array}{l}\text { ds: } 0.56 \pm 0.10 \\
\text { ws: } 0.49 \pm 0.08\end{array}$ \\
\hline
\end{tabular}

$\mathrm{HgT}=$ inorganic $\mathrm{Hg}\left(\mathrm{Hg}^{\circ}+\mathrm{Hg}(\mathrm{II})\right)+\mathrm{MMHg} ; \mathrm{MMHg}$ : monomethylmercury ;

ds: dry season, - ws: wet season; mean values \pm SD or (range).

At the Roche Genipa station, the shape of the vertical concentration profiles obtained on the $35 \mathrm{~m}$ deep water column showed a steep increase of dissolved $\mathrm{HgT}$ as well as dissolved $\mathrm{MMHg}$ with depth which corresponds to the diminution of oxygen (Fig. 2). Dissolved MMHg concentrations were more than 10 times higher in bottom waters (below $10 \mathrm{~m}$ ) compared to surface concentrations, with highest concentrations up to $0.6 \mathrm{ng} \mathrm{l}^{-1}$ with a corresponding percentage of MMHg compared to $\mathrm{HgT}$ of $20 \%$.

The observed difference in dissolved $\mathrm{HgT}$ concentrations in oxic and anoxic parts of the reservoir indicates that the principal source of mercury in the water column are soils flooded by the dam impounding as also shown for temperate water reservoirs [6, 7]. Forest soils in French Guiana contain relatively high $\mathrm{Hg}$ concentrations compared to other Amazonian soils [8]. During the dry season, mercury 
released from sediments may accumulate in the bottom layer of the reservoir because of relatively low mixing processes [7].

The MMHg concentration profiles in the water column suggest that methylation occurs mainly in anoxic waters, below $10 \mathrm{~m}$ depth, and in surface sediments in the Petit Saut reservoir, in relation with the activity of sulfate reducing bacteria. Indeed, during the wet season, the dissolved $\mathrm{MMHg}$ profile shows a similar vertical distribution as sulphides. The water layer where MMHg and S(-II) concentrations rapidly increase with depth is located between 10 and 20m [7].
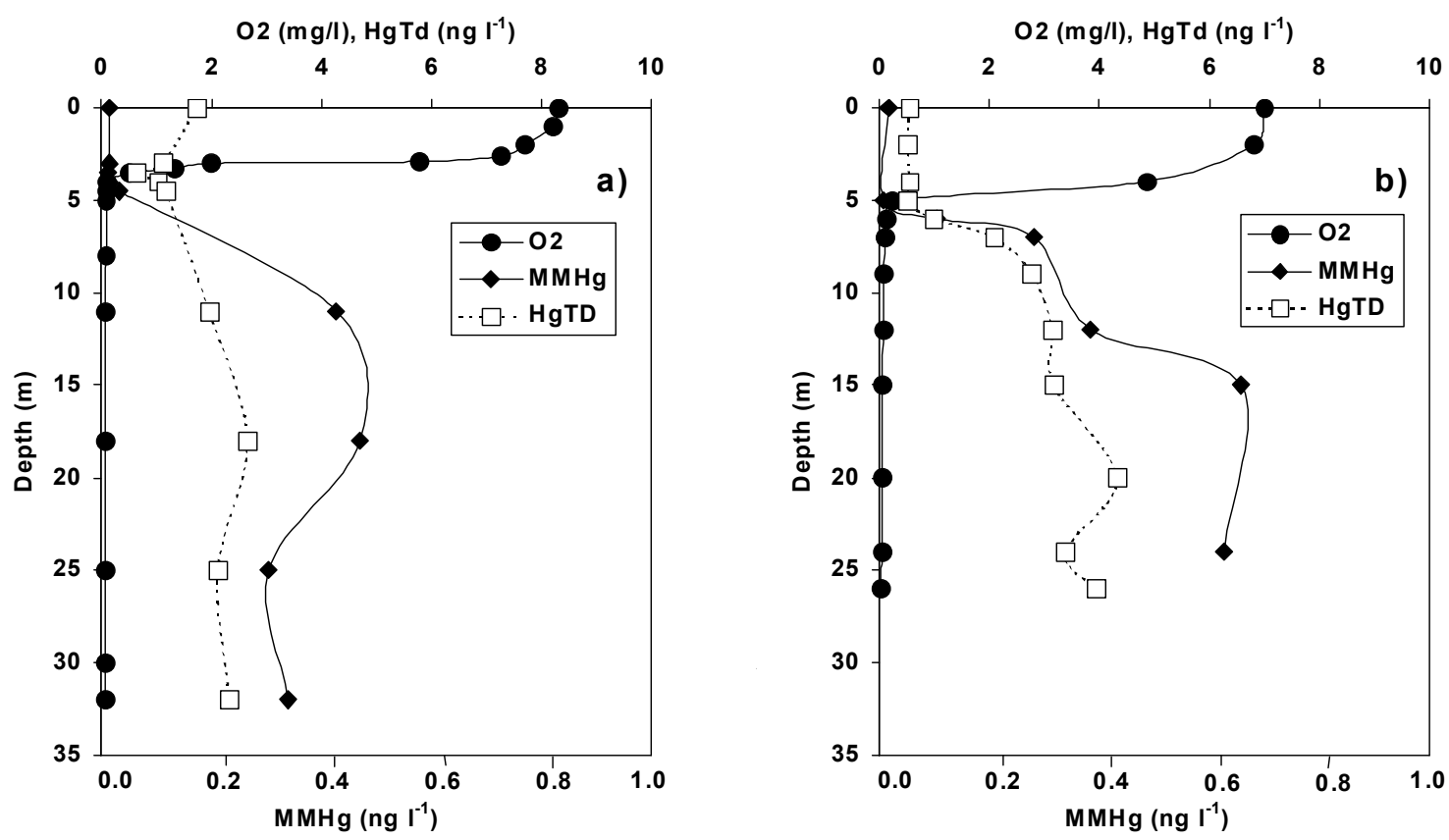

Figure 2. Vertical profiles of mercury concentrations at Roche Genipa station : a) wet season ; b) dry season.

Dissolved MMHg concentrations measured in the waters flowing through the turbine at the base

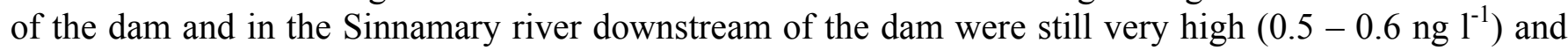
constituted 20 to $35 \%$ of the dissolved HgT (Table 1). Concentration of dissolved HgT averaged about 2

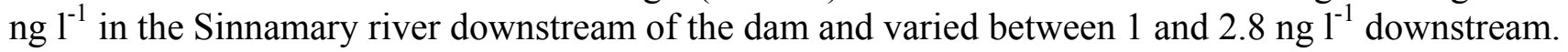

In the estuarine waters, preliminary results showed that dissolved $\mathrm{HgT}$ concentrations were lower than $0.5 \mathrm{ng} \mathrm{l}^{-1}$ for a salinity of 24.4 PSU and the MMHg represented about $1 \%$ of the $\mathrm{HgT}$, a fraction similar to what is usually found in this type of environment.

\section{Acknowledgements}

This work was supported by the CNRS/PEVS, "Mercury in French Guiana" research program, the E.E.C. Feder funds and the French Ministry of the Environment. The authors are grateful to authorities in French Guiana and to the "Chasse \& Pêche" Company for assistance during the setting up and follow-up of the missions. T. P. acknowledges the support of a fellowship from the French Ministry for Foreign Affairs.

\section{References}

[1] Programme "Mercure en Guyane", Rapport final- partie I. (2001) 72pp.

[2] Coquery M. and Cossa D., J. Sea Res. 34 (1995) 245-257.

[3] EPA (U.S. Environmental Protection Agency). Method 1631, (1999) 33p.

[4] Horvat M., Liang L. and Bloom N.S., Wat. Anal. Chim. Acta. 282 (1993) 153-168.

[5] Roulet M., Lucotte M., Canuel R. et al., Sci. Tot. Environ. 213 (1998) 203-211. 
[6] Mucci A., Lucotte M., Montgomery S., Plourde Y., Pichet S., Tra H.V., Can. J. Fish. Aquat. Sci. 52 (1995) 2507-2517.

[7] Peretyazhko T., Van Cappellen P., Coquery M., Meile C., Musso M., Regnier P., Charlet L., Biogeochemistry (submitted).

[8] Roulet M. and Lucotte M., Water Air Soil Pollut. 80 (1995) 1079-1088. 